\title{
Phosphorus Supply Chain-Scientific, Technical, and Economic Foundations: A Transdisciplinary Orientation
}

\author{
Michael C. Mew ${ }^{1,2}$, Gerald Steiner ${ }^{1}$ and Bernhard Geissler ${ }^{1,3, *(1)}$ \\ 1 Department of Knowledge and Communication Management, Danube University Krems, \\ Dr. Karl-Dorrek-Straße 30, 3500 Krems, Austria; michaelmew99@gmail.com (M.C.M.); \\ gerald.steiner@donau-uni.ac.at (G.S.) \\ 2 Phosphates, CRU International, Chancery House, 53-64 Chancery Lane, London WC2A 1QS, UK \\ 3 Faculty of Geosciences, University of Resources TU Bergakademie Freiberg, Geoengineering and Mining, \\ Akademiestraße 6, 09599 Freiberg, Germany \\ * Correspondence: bernhard.geissler@donau-uni.ac.at
}

Received: 12 March 2018; Accepted: 3 April 2018; Published: 5 April 2018

\begin{abstract}
Natural mineral resources, such as phosphates, represent global assets of tremendous economic value to stakeholders. Given its special characteristics and its essentiality for all life on Earth, phosphorus $(\mathrm{P})$ bears additional value to society as it is both indispensable and not substitutable. Most peers in the field, as well as those coming to phosphorus research, are aware of the complex underlying system dynamics of the P supply chain. In view of the manifold problems involved, scientists from various disciplines as well as practice need to find (new) ways to generate, utilize, transfer, and integrate knowledge. This manuscript serves as a best-practice example as it originates from a long-lasting science/practice collaboration and is the result of a mutual learning process. As a cornerstone of the special issue on "Phosphorus Circular Economy: Closing Loops through Sustainable Innovation" we provide state-of-the-art scientific knowledge as well as practical expert insights from the perspectives of geology, technology, economics, and policy making. This manuscript shall help scientific peers, the public, respective companies, and policymakers to address the issue of sustainable phosphorus management.
\end{abstract}

Keywords: sustainable mineral resource management; phosphate rock; mineral raw materials; phosphate fertilizer; pricing; raw material economics; phosphorus

\section{Introduction}

Phosphorus (P) is essential for all life on Earth and, unfortunately, not substitutable, or as Asimov [1] once stated: "We may be able to substitute nuclear power for coal, and plastics for wood, and yeast for meat, and friendliness for isolation-but for phosphorus there is neither substitute nor replacement". In addition to potash $(\mathrm{K})$ and nitrogen $(\mathrm{N})$, phosphorus represents the third major macronutrient. It is a crucial building block of modern-day mineral fertilizers, and thereby important for global food security. Simultaneously, P also represents a hazard for the environment, particularly for rivers and soils, and involves severe mitigation and abatement costs. Primary phosphates are produced almost exclusively by the mining of phosphate rock (PR) deposits of igneous or sedimentary origin. These are, consequently, finite. Given phosphorus's attributes of being essential, finite, non-substitutable, and having a dissipative use structure, humankind faces the major challenge of utilizing this limited resource in a way that promotes sustainable development to include intra- and intergenerational fairness. 
Comprehensive investigations along the phosphorus supply chain demonstrate how important it is to provide an extended knowledge basis that goes beyond single scientific disciplines for dealing with such complex and societally relevant challenges. The complexity of such challenges calls for multidimensional knowledge integration in a transdisciplinary manner. As pointed out by Scholz and Steiner [2], "the merging and relating of different types of perception, knowledge, and valuations in an integrated manner" is crucial. First, the expertise of various disciplines needs to be taken into account for understanding the system of the phosphorus supply chain (e.g., its scientific, technical, social, and economic implications); second, these complex problems cannot be solved by science alone but require an extended discourse between science and practice; and, third, organizational means such as co-leadership between science and practice are foundational within a transdisciplinary setting. These measures are necessary to capture the relevant guiding questions (from a societal as well as a scientific perspective), to allow for joint problem identification and definition, and to enable a thorough system understanding and the development of potential future scenarios, which include the understanding of the effects of possible interventions. Hence, transdisciplinarity allows for mutual learning between science and practice and multidimensional knowledge integration (i.e., interdisciplinarity, integrated systems analysis, integrating different modes of thought, integrating interests and worldviews from different stakeholders, and relating different cultures and religions) for consensus building and capacity building regarding sustainable transition based on socially robust orientations (e.g., [2-4]).

At a global level, the phosphorus-supply chain was first comprehensively tackled by the Global TraPs project (i.e., Global Transdisciplinary Processes for Sustainable Phosphorus Management; 2010-2015; see also http://www.globaltraps.ch/) by an international team of scientists and practitioners "to ensure that future phosphorus use will be sustainable, improve food security and environmental quality, and will provide benefits for the poor" [5]. Based on the fundamental principles of transdisciplinarity, which are briefly described above, Global TraPs aimed to engage key stakeholders from practice and scientists from various disciplines (e.g., including geology, mining, chemical engineering, and soil and plant sciences, agricultural and environmental sciences, social sciences and economics, and behavioral and decision sciences) in a mutual learning process, with the goal to enhance our understanding of the complex and societally relevant system of the comprehensive phosphorus supply chain and, ultimately, with respect to sustainable phosphorus management. The overarching guiding question was the result of a mutual discourse between science and practice: "What new knowledge, technologies and policy options are needed to ensure that future phosphorus use is sustainable, improves food security and environmental quality and provides benefits for the poor?" Based on this common basic understanding, critical questions targeting the single nodes of the supply chain were generated. Therefore, co-leadership between science and practice representatives together with a transdisciplinarity facilitator was realized at every single phase of the supply chain (from exploration, mining, processing, and use, to dissipation and recycling) and the cross-cutting issue of trade and finance. Furthermore, the steering committee, advisors, and project managers were also composed of representatives from science and practice. A specific knowledge integration unit complemented the overall project organization. While resulting in "Sustainable Phosphorus Management: A Global Transdisciplinary Roadmap" [6] this transdisciplinary project also laid out the foundation for extended research in fields such as phosphate rock mining or phosphorus circular economy (e.g., see the Transdisciplinarity Laboratory Sustainable Mineral Resources-SMR TdLab: www.donau-uni.ac.at/smr-tdlab).

Transdisciplinarity will involve different characteristics along the collaborative problem-solving. Hence, a transdisciplinary orientation does not imply that experts from science and practice will continuously work together across all project phases. Instead, the transdisciplinary approach may characterize an initial phase to achieve a common understanding of potential problems, system characteristics, and data peculiarities (e.g., access to data, and characteristics of different data sources). This joint endeavor might then be followed by intensified working processes within each group's own 
"arena". Transdisciplinarity may thereby provide a sophisticated basis for going into depth within not only interdisciplinary but also single disciplinary investigations.

\subsection{In a Nutshell: Terms and Definitions along the Phosphorus Supply Chain}

First, we distinguish the generic terms phosphorus $(\mathrm{P})$ and phosphates from the more specific elemental phosphorus $\left(\mathrm{P}_{4}\right)$ and phosphate rock (PR). Furthermore, we introduce the most relevant intermediates along the supply chain as well as clarify the concepts of reserves, resources, and geopotential in brief.

The difference between phosphorus ( $\mathrm{P}$ in the general sense and $\mathrm{P}_{4}$ when referring to the commodity) and phosphates stems from their chemical compositions. While the terms $\mathrm{P}$ and $\mathrm{P}_{4}$ represent the single chemical element and its commodity respectively, phosphates are compounds where phosphorus is bonded with oxygen and other elements in apatite-group minerals [7]. PR (i.e., rock phosphate or phosphorite) is a mineral assemblage containing a significant amount of phosphorus in apatite-group minerals. $\mathrm{PR}$ is often (or commonly) referred to as $\mathrm{P}_{2} \mathrm{O}_{5}$ (i.e., phosphorus pentoxide). To be more precise, $\mathrm{P}_{2} \mathrm{O}_{5}$ does not exist as a mineral; rather, it is a convenient and standard measure of the phosphorus content of any product. The phosphate minerals in PR vary widely in composition as the mineral apatite $\left[\mathrm{Ca}_{5}(\mathrm{~F}, \mathrm{OH}, \mathrm{Cl})\left(\mathrm{PO}_{4}\right)_{3}\right]$ occurs in many different forms [8].

It is necessary to further distinguish PR-ore as the PR in the ground prior to mining (sometimes referred to as a run of mine ore) from marketable PR concentrate (PR-M) as the saleable product post-beneficiation (i.e., upgraded ore, typically with grades above $28 \% \mathrm{P}_{2} \mathrm{O}_{5}$ ). The average grade of PR-ore is $17.3 \% \mathrm{P}_{2} \mathrm{O}_{5}$, whereby it strongly depends on the origin. While igneous ore grades are often in one-digit regions, sedimentary PR-ore grades might reach mid-twenty levels [9]. Besides the possibility of directly applying PR-M to fields, the chemical treatment of PR-M leads to various downstream products. The most common first step, by far, is to produce phosphoric acid (PA), usually by sulfuric acid (SA) attack — known as the wet process (producing wet-process acid, WPA)—which is then used in the production of a range of phosphate fertilizers (PF) or animal feed ingredients (AFI). By reacting PR with less SA, lower-grade superphosphate fertilizers (SSP) are produced directly. Some WPA is upgraded to purified PA (PPA) to produce industrial chemicals or for food-grade applications. Pure phosphoric acid for industrial and food end-use used to be produced mainly through the so-called thermal route, the reduction of PR-M or PR-ore in a furnace to produce $\mathrm{P}_{4}$. This $\mathrm{P}_{4}$ is then used directly to produce a host of industrial products or dissolved in water to produce a pure phosphoric acid (known as industrial PA or technical PA). Due largely to the fact that it is an energy-intensive process, today there is only a diminished $\mathrm{P}_{4}$ industry, centered mostly in Kazakhstan, Vietnam, and China, together with a residual industry in the US [10]. As purification techniques have become more economically viable, PPA production has taken over progressively from $\mathrm{P}_{4}$ in the production of phosphate salts.

PR-ore reserves, resources, and geopotential (i.e., resource-base) are differentiated by two determining factors: economic viability and geological assurance. Reserves are the part of resources that are well known and economically extractable with the current available technology under acceptable socio-ecological conditions. Resources are geologically known (to a certain extent) but without current established economic feasibility. The geopotential, is mostly known only by geological reasoning [11]. An additional term, reserve-base, was a measure used by the former US Bureau of Mines to indicate the share of resources with a reasonable potential of becoming a reserve within a mine's planning horizon (mostly in the range of 5-10 years) [12].

To avoid confusion, any statement regarding PR reserves should always make clear whether the figures given refer to PR-ore or PR-M, since historically both systems have been used in reporting.

\subsection{The Role of Phosphate Rock and Fertilizers in Our Society: Past and Present}

More than $80 \%$ of the over 200 million tons of PR-M produced each year is used in chemical fertilizers for the production of food, either for direct human consumption or for the feeding of 
animals for meat production [6]. Morse and Glover [13] showed in their 20th century review that the PF demand for farm commodities in the US increased at the beginning of the 20th century until World War I (WWI) and then again after the Great Depression. The combination of technological advancement and government price supports, export subsidies, and conservation efforts led to an overall area of 400 million hectares of farmland in the US, which, remarkably, remained constant until 1980. Farm production and therefore efficiency increased dramatically during this period, feeding the rising demand of a growing population (from approximately 100 million in 1920 to approximately 225 million people living in the US by 1980). Large parts of this efficiency increase can be attributed directly to the application of mineral fertilizers. Generally, about half of today's crop yield is directly related to the utilization of mineral fertilizers $[3,14,15]$.

While land-use efficiency (i.e., yield per hectare) has improved significantly, the total nutrient use efficiency of phosphorus (i.e., the proportion of P mined from PR deposits being digested in human food) remains at very low levels. Losses of phosphorus along the supply chain from PR-ore to human consumption can amount to up to 95\% [16]. We do not consume P in the sense that we consume fossil fuels, but we do dissipate the element ultimately into seawater, where concentrations are low enough to be essentially unrecoverable from today's standpoint.

Figure 1 shows the global development of PR-M production (blue line) between 1913 and 2014 in comparison to the population development (orange line). We find a more or less similar trend for the first 40 years, followed by a steeper increase of PR-M production after WW II until 1990. Current annual PR-M production levels lie in the range of 210-250 million metric tons (depending on data source; [17]) and are well above the pre-1990s levels.

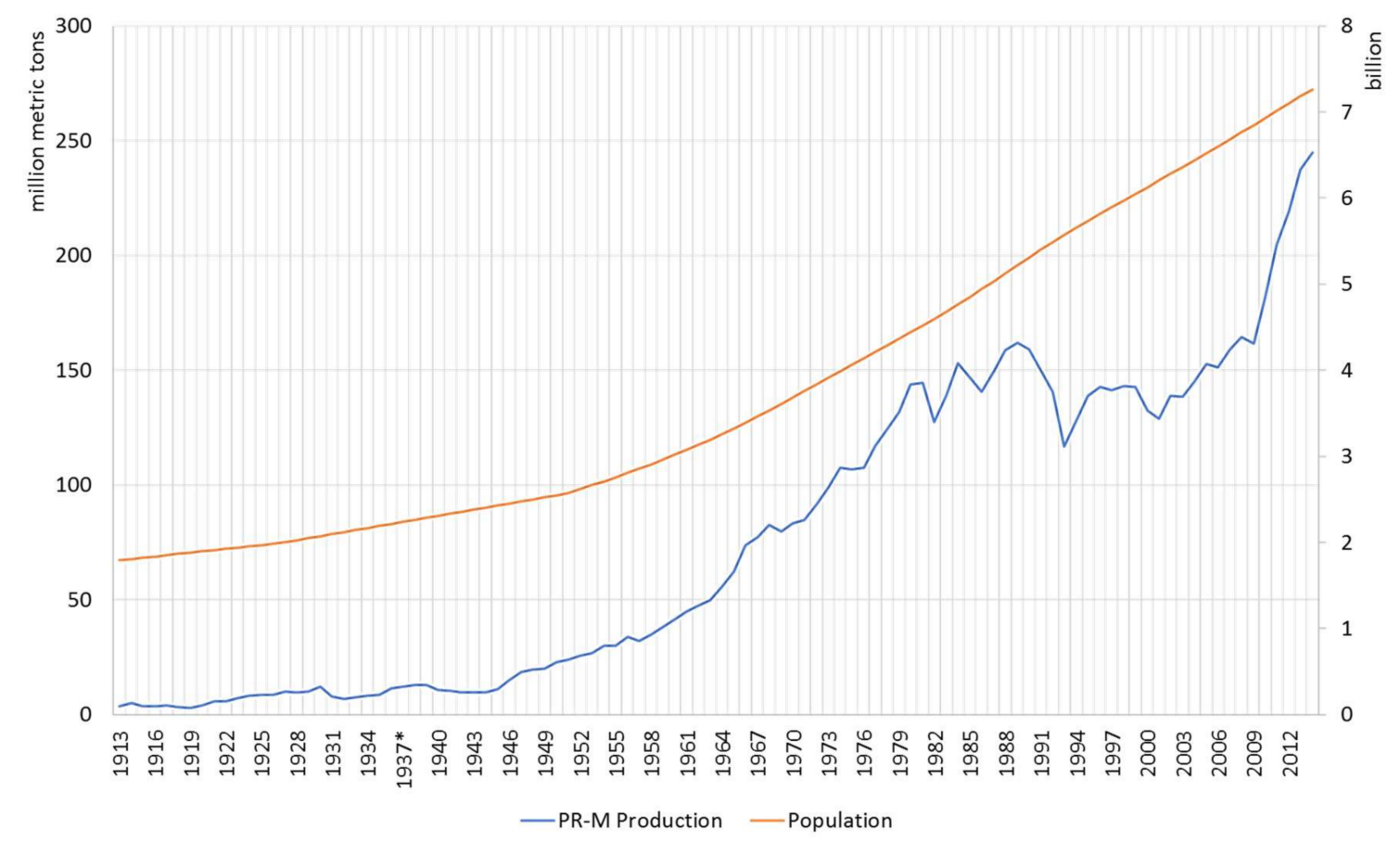

Figure 1. Developments of global PR-M production (linear interpolation for 1937, compiled from the British Geological Survey) and global population since 1913 (linear interpolation between 1900 and 1927 and 1927 and 1951, based on Worldometers).

World population approximately quadrupled from 1.79 billion in 1913 to 7.27 billion in 2014, whereas the production of PR-M increased from 3.4 million metric tons in 1913 to 245 million metric tons in 2014 (using data from the British Geological Survey, BGS). Beyond the question of data accuracy, especially in the early years of the study, we see the enormous rise of PR-M in the form of mineral fertilization within the 20th century continuing into the 21st century. Generally, the excess 
consumption of food society-wide in developed countries became possible during the second half of the 20th century when the price of all consumable goods, relative to income, dropped sharply. This social option of overconsumption is based mostly on income growth and revolutionary gains in agricultural production [18]. In terms of available global reserves, current US Geological Survey (USGS) data remain relatively constant at levels between 65 Gt in 2011 and $70 \mathrm{Gt}$ in 2018, resources are estimated at more than $300 \mathrm{Gt}$. These aggregated data sets contain both, PR-M and PR-ore, as some countries report only the latter [19].

Given its relevance for agriculture, the strategic nature of mineral $\mathrm{P}$ is of great importance. As an example, although the US in 2004 was holding the 3rd highest reserve-base and 4th highest reserves [20], it signed a free-trade agreement with Morocco covering phosphate rock most prominently (among other commodities), becoming effective in 2006 [21,22]. Similar negotiations, although with some delay, are going on between the European Union and Morocco. While first negotiations for a Deep and Comprehensive Free Trade Area started in 2013 [23], the deal is currently on hold or even potentially voided by the European Court of Justice because it included the disputed territory of Western Sahara [24].

\subsection{Phosphorus Recovery}

Since $P$ is of a dissipative use structure, it remains (at least theoretically) available to be recovered and used more than once along the supply chain [25]. P is "lost" when it is dissipated to the point at which it is unlikely ever to be economically recoverable. The most commonly identified losses are to water bodies, where the P nutrient is eventually returned to the sea in very low concentrations.

By identifying the points where losses occur along the supply chain, we have the opportunity of recovering $\mathrm{P}$ and re-use it a second or multiple times before it is finally (economically) unrecoverable. Two of the factors driving P recycling are the obligation to consider ways of not disadvantaging future generations' access to $P$ and encountering environmental problems, notably eutrophication of waterways and oceans as a result of excessive algal growth [26].

Recycling of $\mathrm{P}$, in the form of animal manure, has for millennia been a part of agricultural practice. Increased animal stocks have made this a significant source of secondary P. However, recent trends to intensive farming have also resulted in the need to transport manure out of these "hotspots", which adds to the costs of recovery.

Current activities mostly focus on devising methods of removing $P$ from potential sources such as wastewater, manure, or food- and slaughter wastes. Numerous treatment routes have reached the near-commercial application. Most recently, Ohtake and Tsundeda issued a comprehensive state-of-the-art book on P recovery and recycling [27].

\section{Geological Perspective: Availability and Ore Characteristics}

The geosphere addresses the physical availability of P. In terms of frequency either in the Earth's crust (11th place among most frequent minerals) [28] or water (13th place) [29], P holds a position as one of the most abundant elements (amounting to approximately $4 \times 10^{15}$ tons of $\mathrm{P}$ in the Earth's crust [30]). Based on their genetic origin, phosphate deposits are classified as: (i) sedimentary deposits, which were formed as part of marine sedimentary sequences (the most important deposits can be found in US, China, and the Mediterranean belt from Morocco to Saudi Arabia); (ii) igneous deposits, which originated from magmatic activity and occur as apatite-enriched masses, sheets, or veins in alkaline intrusive complexes, in some cases associated with either iron or rare earth elements (REE) (major igneous deposits can be found in Russia, South Africa, Finland, and Brazil); and (iii) guano deposits, which were formed by the accumulation of seabird and bat excrement and occur mostly in the form of calcium phosphate (guano resources are dwindling and no longer play a major role in the global market) [31].

Sedimentary phosphate deposits consist of one or more phosphate beds. Exploratory work allows the resource tonnage of the deposit to be defined down to a specific cut-off grade (i.e., the minimum 
content of valuable product necessary for further economic processing [32]). Beds below the cut-off grade are not included in the reserve figure, given the fact that they cannot be transformed into PR-M economically. Multiple phosphate beds are separated by waste beds. These waste beds are either mined separately (selective mining) or are mined with the phosphate beds and separated as waste during beneficiation. The decision to mine selectively is usually based on various mining parameters, such as the thickness of the waste beds and their mineralogy (hardness and ease of separation). The mineralogy of the phosphate beds determines the optimum beneficiation process and the target grade of concentrate [9].

Deposit mineralogy, bed thicknesses (both ore and waste), overburden thickness (the waste bed lying on top of the first phosphate bed), and ore grades all vary spatially within a single phosphate deposit. The beds are often tilted from the horizontal, sometimes folded and/or metamorphosed by tectonic activity. Metamorphosed beds can be harder and more consolidated than the loose sandy phosphates found elsewhere. Harder beds often require drilling and blasting before mining can take place. Sometimes overburden and other waste beds also have to be drilled and blasted with explosives [9].

Igneous phosphate deposits tend to be part of a massive intrusion, but the phosphate zone within the intrusion can be massive or lenticular. Again, the phosphorus reserve is defined by a cut-off grade, but, in this case, may also require a depth cut-off, derived from the economics of open-pit mining at depth, for the case of open-pit mining. Igneous ores generally are consolidated and require blasting prior to mining. Once the site is cleared, there is little overburden to handle until the pit depth and maximum wall slope dictate that waste rock outside the phosphate zone has to be mined before the pit depth can be extended. The generally simpler mineralogy of igneous deposits often results in a relatively low-grade ore producing a high-grade concentrate, often with a higher than average $\mathrm{P}_{2} \mathrm{O}_{5}$ recovery rate. Igneous deposits in Russia are partly mined underground in a mountainous region of the Kola Peninsula $[9,33]$.

All PR-ores contain a mixture of elements; the level of some (Ca, F, Cl, Al, Fe, Mg, and C) play an important role in downstream processing, whereas others do not impact processing but are important, mainly as potential environmental contaminants $(\mathrm{U}, \mathrm{Th}, \mathrm{Cd}, \mathrm{As}, \mathrm{Se}$, and $\mathrm{Pb})$.

The radioactive element uranium is concentrated particularly in some sedimentary rocks. At times of high $U$ prices, the $U$ content has been recovered at the PA production stage, particularly in the US. However, the fall in $U$ prices has since resulted in the closure of all units. Sufficient radioactive elements pass into the phosphogypsum waste in the industry in Florida to prevent its use as a commercial product [34].

Cadmium levels in PF products have been of concern for several decades since $\mathrm{Cd}$ is accumulative and toxic in humans. Soils that have significant PF additions can accumulate $\mathrm{Cd}$ that, in theory, can pass into some crop varieties. The mechanisms and degree of $\mathrm{Cd}$ accumulation has been the subject of much debate [35,36], but levels have been limited by individual countries. Under legislation currently being enacted, Cd levels in PF are likely to be limited, finally, in the entire EU. Several proposals are theoretically possible, but the most likely is for the level of $\mathrm{Cd}$ in fertilizer products to be limited, initially to $60 \mathrm{mg} / \mathrm{kg} \mathrm{P}_{2} \mathrm{O}_{5}$, then to $40 \mathrm{mg} / \mathrm{kg} \mathrm{P} \mathrm{P}_{2} \mathrm{O}_{5}$ after three years, and $20 \mathrm{mg} / \mathrm{kg} \mathrm{P} \mathrm{O}_{5}$ after 12 years [37].

The impact of this proposed legislation on the sellers of phosphate products (PR, PA, and PF) is not immediately obvious. In PA production, the degree to which $\mathrm{Cd}$ partitions between the acid and the phosphogypsum waste depends on the process used. There is also a possibility of mixing higher $\mathrm{Cd}$ and lower $\mathrm{Cd}$ rock types prior to PA production. These factors make it difficult to quantify the impact on individual PR suppliers, although in general, those suppliers with higher Cd content in their rock will be at a disadvantage compared to those with minimal Cd levels.

Certainly, in the production of SSP, where all the initial ingredients end up in the final product, there is a direct correlation between Cd levels in the PR-M and in the final fertilizer product.

The limiting of the $\mathrm{Cd}$ content in PF products in the EU comes at a time when the EU has placed PR-M on its list of critical raw minerals (in 2014) [38]. The new legislation, if enacted, will further limit 
the sources of PR-M and PF available to European farmers in the immediate future, whereas in the long-run technological innovations might help to overcome this issue.

\section{Technological Perspective: From Exploration to Phosphate Fertilizers}

The Extended Phosphorus Supply Chain (EPSC, Figure 2) comprises all the steps in recovering and using $\mathrm{P}$ from geologic deposits through its final dispersal. Losses of $\mathrm{P}$ are evident throughout the supply chain, implying that there should be opportunities for increased resource recovery [39].

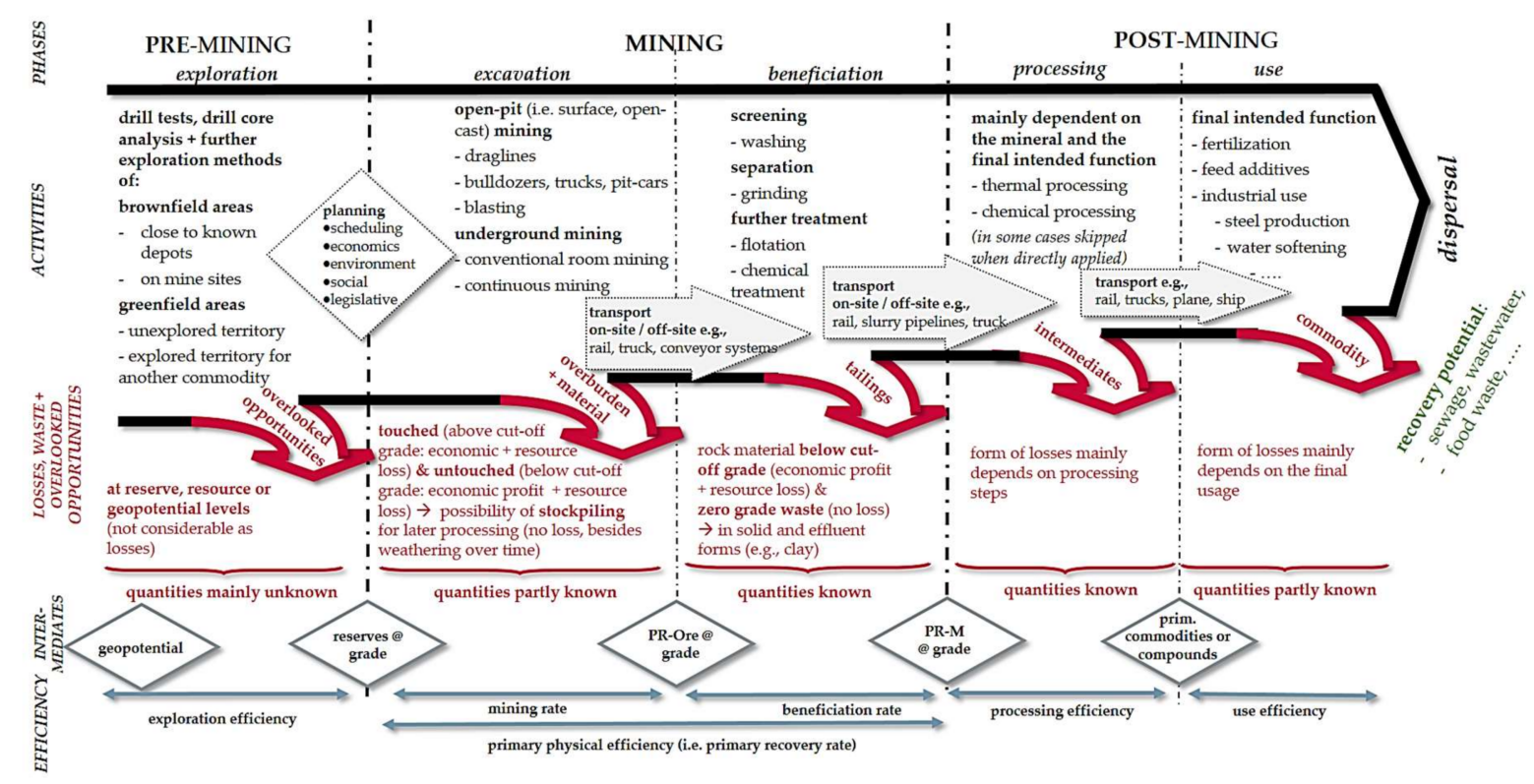

Figure 2. The Extended Phosphorus Supply Chain (EPSC) for the mining phase, based on [9].

\subsection{Pre-Mining: Exploration}

PR deposits are typically first delineated on a broad scale from national geological mapping programs, often performed by government agencies such as geological surveys such as the USGS or BGS. Further detail is obtained by drilling, often by junior mining companies, which normally report deposit tonnages and grades (both average and cut-off) as exploration progresses. For an existing producer, drilling is usually performed to map out future production. To pass from being a resource to a reserve, two criteria have to be met. First, the deposit has to be sufficiently delineated (to specifications outlined in the various mining codes, most of them based on the Committee for Mineral Reserves International Reporting Standard, CRIRSCO) by drilling programs. Secondly, the mining of the deposit has to be economical at today's market price levels. This second factor is more difficult to assess, and often tonnages are quoted as resources rather than reserves, particularly if they are likely to be mined a decade or more in the future. This leads to a two-dimensional characterization incorporating the geological assurance and the economic viability known as the McKelvey Box [40].

Having a cut-off grade to resource delineation inevitably results in some $\mathrm{P}$ being left in the ground intentionally because of its uneconomical characteristic. As a practical rule of thumb, the cut-off grade is approximately half the average ore grade of the deposit [41]. Whether this is counted as losses depends on several factors, such as its grade and its accessibility to future mining.

\subsection{Mining: Excavation and Beneficiation}

The excavation of PR-ore is achieved predominantly by open-pit methods, with underground workings on a major scale found only in Russia. Normal earth-moving techniques are used involving draglines, mechanical shovels, bucket wheel excavators, bulldozers, trucks, etc., all scaled to fit the 
optimum pit-design plan. Drilling and blasting is necessary in some cases where overburden and/or ore are indurated. The mining process takes ore to the first processing step, which is usually a primary crusher for reducing the size of large lumps prior to beneficiation. P losses in this phase result from the inaccurate mining of ore, dust losses, and oversized rejects from the primary crusher [42].

Beneficiation can take many forms, the most basic involving only sizing (crushing or grinding followed by screening), while washing is also common, as is, increasingly, flotation (one or more stages). The latter is especially useful for the processing of fine feeds typically not separable (using conventional wash/size operations) [43]. Other beneficiation techniques less-often used include heavy media separation, calcination (roasting), or magnetic separation, depending mostly on the available technology and the ore's characteristics. Figure 3 exemplarily shows the simplified flowchart for the White Springs PR Mine in Florida.

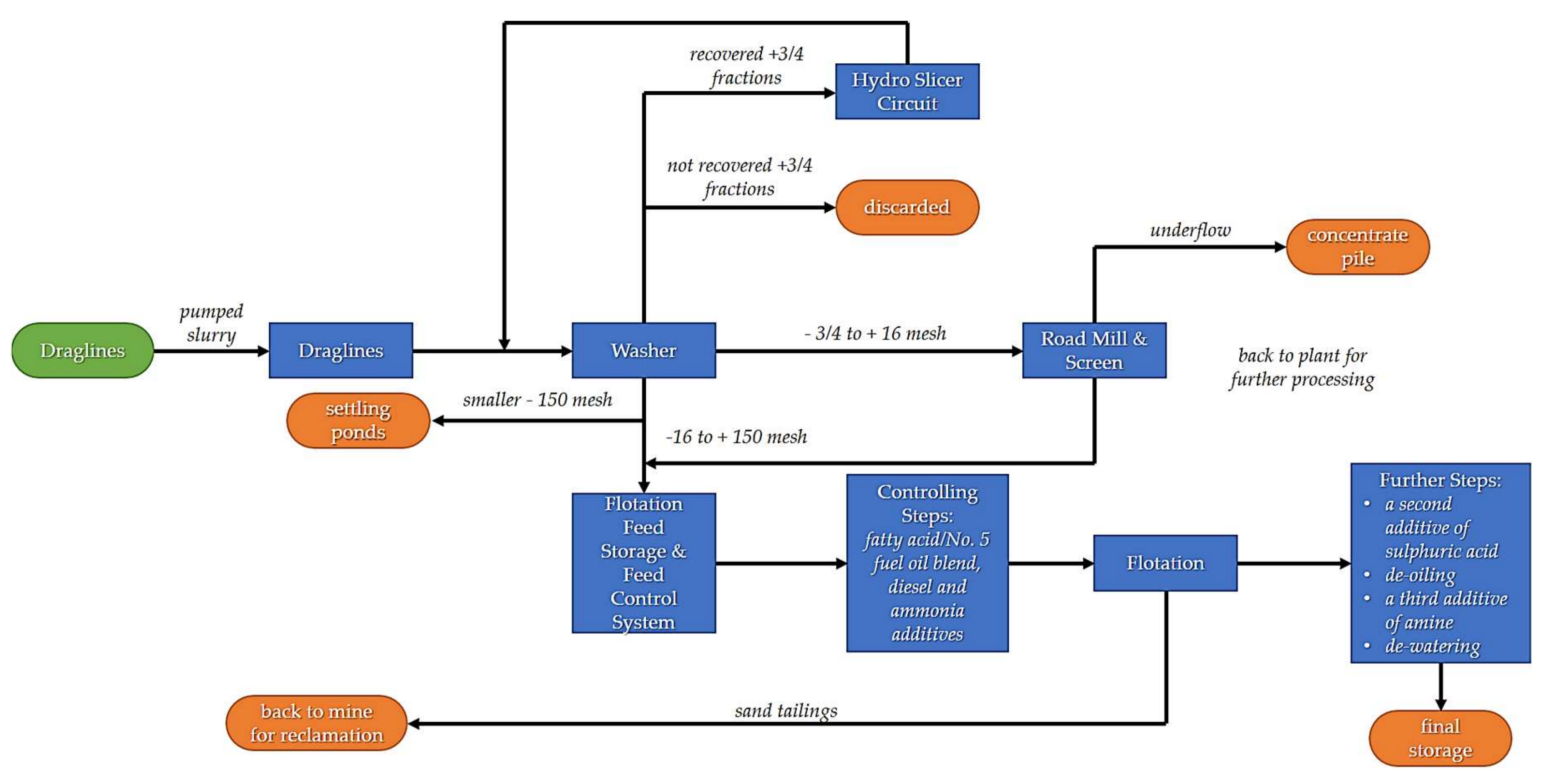

Figure 3. Simplified flowchart of the White Springs Mine located in Florida (US) $[9,44]$

There is a large variation in $\mathrm{P}$ loss levels during beneficiation. The highest recovery rates of over $90 \%$ are seen in some of the multi-stage flotation schemes that treat low-grade igneous PR-Ore in Russia. Operations based on sedimentary ores generally have poorer recovery rates. In the Florida industry, for example, recovery rates can be around $50 \%$ despite multi-stage flotation. Globally, average recovery rates during beneficiation appear to be around $67 \%$ [9]. The product of beneficiation PR-M is either used locally (wet or dry) or is dried and exported.

\subsection{Post Mining: Processing and Use}

The downstream use of PR-M is dominated by the production of PF products for agriculture. Most are made via the production of WPA, although SSP production directly from PR-M is important in some countries. Figure 4 summarizes the relationship of PR-M and the various forms of PFs. Diammonium phosphate (DAP), monoammonium phosphate (MAP), and triple superphosphates (TSP) represent the main forms of PFs, and NPK stands for the group of fertilizers containing all three major macro nutrients, namely nitrogen, potassium, and phosphorus. Production processes tend to have low $\mathrm{P}_{2} \mathrm{O}_{5}$ losses, with most WPA processes achieving over $90 \%$ recovery of $\mathrm{P}_{2} \mathrm{O}_{5}$ and $\mathrm{PF}$ production and often close to $95 \%$ recovery. 


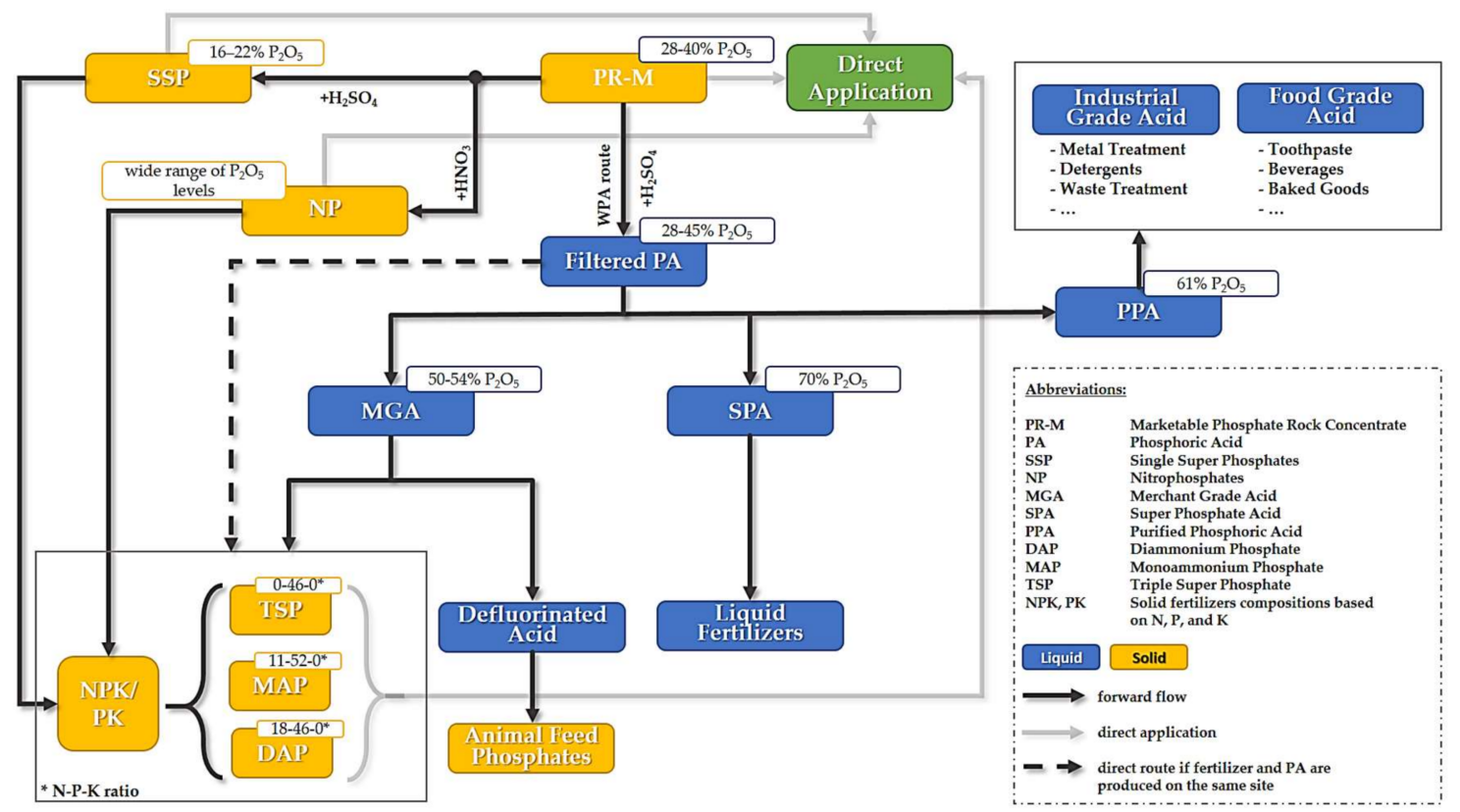

Figure 4. Relationship of PR-M and the different kinds of PFs extended from [45].

Losses of $\mathrm{P}_{2} \mathrm{O}_{5}$ on the farm, through the actions of erosion and leaching, tend to be much higher, and their consequences are more pronounced in terms of their contribution to the eutrophication of water bodies and, in some cases, the creation of dead zones in the ocean. Plants obtain their $P$ nutrient requirement from $P$ compounds in solution in the soil [46]. Part of the PF added goes into solution and is available to plants. The remainder is "fixed" in the soil [47] as low-solubility compounds. These compounds are then resolubilized over time, providing a second source of $\mathrm{P}$ to plants [48]. This mechanism is important for two reasons. In terms of demand elasticity in advanced agricultural systems, it means that product yields are unlikely to be impacted by one or even two years of non-application of PF products. Extremely high fertilizer prices, therefore, tend to result in a short-term drastic reduction in PF offtake. Secondly, it means there are always P minerals in the soil system that can be leached in solution by the excess run-off of water or can be taken out of the system as insoluble compounds as part of soil erosion.

\section{Economic Perspective: The Phosphate Market and Essential Price Economics}

As part of the very heterogeneous group of industrial minerals, marketable phosphate rock (PR-M) itself varies greatly in terms of certain characteristics such as grade, composition, and contamination. Usually, trading PR-M requires mostly practical experience, in addition to an understanding of the market and its behavior. Therefore, the scientific literature on PR-M trading is very limited. Given the transdisciplinary intention of this manuscript, we aim to link (basic) scientific literature to almost 40 years of practical consultancy experience in the global phosphate industry.

\subsection{Price Setting Mechanisms: Theory and Industry Practice}

In contrast to basic metals, which are traded on open exchanges on many public commodity markets such as the London Metal Exchange (LME) [49,50], the price levels of products such as PR-M, PA, and PF are set largely by private contracts agreed upon between buyers and sellers. Although these prices are set individually, time series on PR-M prices are made publicly available by institutions such as the Index Mundi [51] or the World Bank [52], where the data usually refer to a standardized contract determined by industry publications such as Fertilizer Week, compiled by consultancy firms such as CRU International. 
Prices attached to these contracts reflect the balance of product supply and demand in the market, within the concurrent economic framework. Below that relatively simple statement, there lies a complex web of interaction, in particular, what we refer to as the "economic framework" that, in reality, comprises a large number of factors that act either directly or indirectly on:

- Supply (determinants such as input costs, technological change, strikes or other disruptions, or market structures or governmental activities [53])

- Demand (determinants such as income or economic activity, price, technological change, consumer preferences, or governmental activities [53])

In the case of PR-M, specific factors altering the supply side might be the availability of capital, environmental regulations, or interest rates. In terms of demand, factors such as food-price inflation, taxes, or the development of biofuel capacities might affect the market balance. Determinants such as energy and oil prices, currency developments, or freight rates might affect both supply and demand.

Every time a new phosphate price level is set, it also feeds back into industry economics. If supply is in excess of demand, prices tend to fall. Lower prices tend to reduce supply (short term by reducing profitability and longer term by discouraging new supply projects) and encourage demand. Conversely, when the supply runs short of the demand, prices tend to rise. Higher prices encourage more supply into the market (higher-cost producers can still make a profit) and reduce demand (particularly relevant in the phosphate sector due to the buildup of a soil reserve of $P$ in many cases). This basic economic mechanism is generally described through the "cobweb theorem", or referred to as a feedback control mechanism [54,55]. Particularly, in terms of market power, it is of great importance to distinguish between short- and long-term behavior of market participants [56]. The action of each part of the supply-demand economics price system (for PF, PA, PR-M, and other commodities) is linked to every other part.

Market prices are set by individual exporters and consumers through negotiation. Generally, producers are looking to raise prices and consumers to reduce them. However, for producers, the equation is more complex, with overall revenues, comprising prices and volumes, being more relevant than price levels alone. The larger the increase in price demanded by the exporter, the more likely he is to lose tonnage through demand elasticity, as well as potentially losing tonnage to a competitor, which might not support the price increase entirely. Overall business objectives can also be different for private companies and state-owned entities. For private companies, shareholder pressure tends to push for short-term profits, whereas a state-owned producer is likely to have a long-term view. The degree of state-ownership is, therefore, relevant in the analysis of economic behavior of the market [33].

The price of a commodity is determined by each sequential commercial sale under contract. The price is usually quoted in each contract either based on ex-supplier port $\left(\mathrm{P}_{\mathrm{ex}}\right)$ or delivered to consumer import port $\left(\mathrm{P}_{\mathrm{im}}\right) . \mathrm{P}_{\mathrm{ex}}$ quotes are usually on a free-on-board $(\mathrm{FOB})$ or free-alongside ship (FAS) basis, the difference being the cost of loading the vessel. Various terms describe delivered prices, C\&F (costs and freight), CIF (costs, insurance, and freight), etc., depending on which elements of freight, insurance, and other shipping costs are included in the price quoted in the contract. These predefined agreements are defined by the International Commercial Terms (Incoterms) from the International Chamber of Commerce (ICC) [57]. Basically, in contracts citing a $P_{e x}$, the importer (buyer) pays for the shipment costs, whereas in $\mathrm{P}_{\text {im }}$ contracts the exporter (seller) pays for shipment.

Contracts of sale in the phosphate sector are usually quoted in US dollars. One type of sales contract is where a single cargo of product is to be supplied at a specified time in the future. For such "spot sales", shipment is normally fairly close to the contract agreement date (within 30 days is common). PF products are most often sold on spot contracts. PR and PA are generally sold on term contracts; for PA, a price is often agreed upon for a tonnage that is to be delivered in several shipments over a 3-, 6-, or 12-month period. In PR sales, some term contracts are similarly for a duration of 3, 6, or 12 months. 
Historically, the prevalence of the annual contract system reflected the need for PR consumers to ensure a continuous supply of PR for their plants. This was reinforced by the fact that PR products vary in grade and levels of other chemical constituents that impact the processing of PR, particularly the production of PA through the wet process. A new rock supply is usually preceded by the delivery of at least one trial cargo to allow a plant-level assessment of the way the rock product performs as a raw material.

With exporters and importers acting rationally in the manner of a Homo economicus [58], there are many factors that drive an exporter's decision to demand an increase in asking prices, just as a combination of factors drives a buyer's decision to accept a price or reject it.

The prevailing factors acting on the market are not driving prices directly but rather influencing the behavior of the individual seller and buyer; a combination of factors sets the economic framework within which they make their decisions. The influence of each factor will clearly vary from seller to seller and from buyer to buyer, Table 1 provides an overview on arguments from both perspectives.

Table 1. Factors impacting price negotiations in PR-M, PA, and PF markets.

\begin{tabular}{|c|c|c|}
\hline & Seller's Perspective & Buyer's Perspective \\
\hline PR-M & 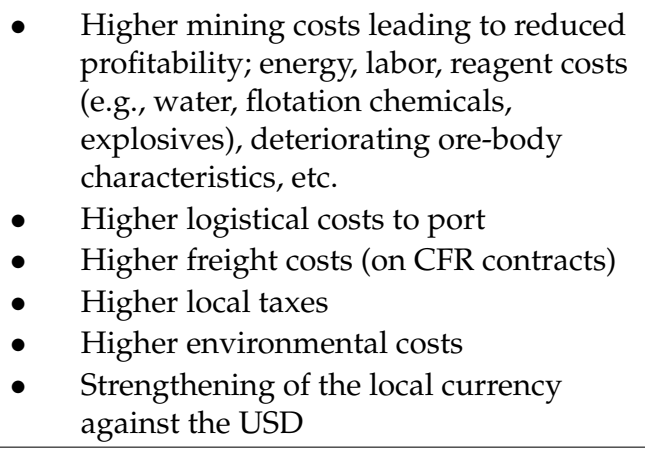 & $\begin{array}{l}\text { - Higher costs involved in processing the } \\
\text { rock (energy, labor, reagents, taxes, } \\
\text { environmental costs, etc.) leading to } \\
\text { reduced profitability } \\
\text { - } \quad \text { Lower sales prices for the products } \\
\text { produced from the rock } \\
\text { - } \quad \text { Higher freight costs (on fob contracts) } \\
\text { - Offers from other PR, PA, or PF } \\
\text { suppliers at better prices }\end{array}$ \\
\hline PA & $\begin{array}{l}\text { - Higher sulfur or sulfuric acid costs } \\
\text { or prices } \\
\text { - Higher phosphoric acid conversion costs } \\
\text { (energy, chemical reagents, water, labor, } \\
\text { gypsum disposal, etc.) } \\
\text { - } \quad \text { Higher freight costs (on CFR contracts) } \\
\text { Rising PF prices }\end{array}$ & $\begin{array}{l}\text { Higher costs involved in processing the } \\
\text { acid (energy, labor, reagents, taxes, } \\
\text { environmental costs, etc.) leading to } \\
\text { reduced profitability } \\
\text { - } \quad \text { Lower sales prices for the products } \\
\text { produced from the acid } \\
\text { - } \quad \text { Higher freight costs (on fob contracts) } \\
\text { - Offers of similar grade/quality PA from } \\
\text { other suppliers at better prices } \\
\text { - Falling PF prices }\end{array}$ \\
\hline PF & $\begin{array}{l}\text { - Offer based on market price reports and } \\
\text { competitive position }\end{array}$ & $\begin{array}{l}\text { - Acceptance based on competing offers } \\
\text { from suppliers }\end{array}$ \\
\hline
\end{tabular}

It is not the case that exporters attempt to raise prices all the time but fail. There are numerous factors that are considered by exporters before they make a decision regarding price policies. The price leader, in particular, has to be careful not to upset customers by asking for an unjustified increase in price, since others may decide to undercut this price and, potentially, take customers away from the price leader.

Phosphate Rock: Typically, a contract will be renewable on a quarterly, semi-annual, or annual basis with relatively little recent price information in the market on which to base a discussion. Discussions generally begin toward the end of the current delivery period. Price and tonnage are set for the next delivery period. If a customer does not agree to the requested price level, the exporter might decide that better returns are available in other markets or might (in some situations) decide to produce more PA or PF products for sale rather than rock. 
Phosphoric Acid: Typically, a contract will cover a spot sale or be renewal on a quarterly or semi-annual basis. There will again be relatively little recent price information in the market on which to base a discussion. Discussions generally begin toward the end of the current delivery period. Price and tonnage are set for the next delivery period.

Phosphate Fertilizers: Usually, an exporter offers single or multiple cargoes to a trader or importer. Market prices are much more transparent, and the most recent PF market price trends, coupled with potential offers from competing suppliers, dictate the final price offer and whether it is accepted. With PF sales, there is much less discussion over price than with the raw material products. An offer is made, either directly or through a tender process, and the offer is accepted or rejected.

Arguments put forward by suppliers and their customers largely reflect the changing economics in the industry, but it is the supply/demand balance that determines whether, for example, higher production costs for producers can be passed on to consumers in the form of higher prices. If consumers are able to refuse to buy at a higher price because the same or equivalent product is available from another supplier at a lower price, this will prevent prices from rising, and the producer's higher costs will result in his or her lower profit margins instead.

When contemplating an aggressive hike in prices, an exporter has to be confident about his price proposal in order to prevent losing customers. Since new PF sales are made on a daily basis, PF prices are naturally more volatile than those for PA or PR. It makes intuitive sense that, in a period of sustained price strengthening, it will be PF prices that move upward first, while PA and PR contract prices react to these changes when contracts come up for renewal. Purchasers of PR are likely to be using it to produce PA or PF products for sale. Of course, to react to a positive price signal in the PF sector, the PA and PR price negotiations are also impacted by supply/demand issues within the PA and PR markets themselves.

If the supply/demand balance in the PR market, for example, is tight (the demand exceeds the supply), it should result in higher prices. However, most PR is used in the production of PF products, and if prices in that market are low, it is much harder for PR prices to rise. Conversely, if the supply/demand balance in the PR market is loose (the supply exceeds the demand), then prices are unlikely to increase, even if downstream PF prices are high due to the competition within the PR market. However, two factors reduce the direct competition in the PR market. The first of these is the fact that the PR market is not homogeneous-there is great variability in the grade and quality of rock being offered and the substitution of one product with another is not straightforward. The second factor is that Morocco has, historically, had a large share of the PR export market and also a large share of the export PA market. In some cases (the period 2010-2015 being an example), Morocco has been able to use its dominant position in the market to support PR and PA prices, even at times of decreasing PF pricing.

A quantitative data analysis was performed by Weber et al. [59] in order to address price dynamics of PR, PF, and other commodities. By using regression models and transdisciplinary workshops they derived a draft system model of factors influencing mineral fertilizer prices, such as raw material prices ( $\mathrm{S}, \mathrm{P}, \mathrm{N}$, and $\mathrm{K})$, energy and transportation, supply and demand settings, financial factors such as available funds or currency values, or overall food prices.

Adjustments are invariably built into the PR sales contract itself to compensate the supplier or the buyer for variations in the grade of rock supplied, moisture content, and levels of various other chemical elements, the most common being $\mathrm{Cl}, \mathrm{MgO}, \mathrm{Fe}_{2} \mathrm{O}_{3}, \mathrm{Al}_{2} \mathrm{O}_{3}$, and organic $\mathrm{C}$. Typically, each contract will specify a target level for each element and target moisture content. It will then specify an adjustment in price for a variation over or under this target level. Usually, there is also a cut-off level beyond which the cargo can be rejected. A chemical analysis is performed on each cargo prior to its leaving the export port and upon arrival at the import port. These analyses are then compared, and a level for each component is calculated using a formula set out in the contract. The full contract price is registered at the export customs point since adjustments can be assigned only retroactively. Rebates on the contract price, such as loyalty, tonnage, or off-contract bonuses, can be 
agreed upon individually based on various parameters. A further factor in economic considerations is the type of ownership. For private companies, the time-scale for such calculations tends to be short; typically, shareholders will make a judgment based on quarterly earnings releases. For public companies, short-term profitability will be important, but often there will be other considerations such as the development of the economy, the provision of jobs, etc. A significant proportion of PR-M producers are government controlled. This can lead to increased opportunities for coordinated pricing or other cooperation in the future.

\subsection{Market Developments}

The three decades following the 1970s saw growth in PF demand globally, centered mainly in developing nations, particularly China, and driven by increasing populations and increasing prosperity, which led to higher consumption of meat-based products. Initially, this growth in PF demand in China was supplied by PF imports (mainly from the US), but, by the mid-1990s, the supply capability of PR within China itself was rapidly developing [33]. The development of new PR capacity was so successful that initially China became a significant source of export PR-M, but increasingly through the end of the 1990s and into the new millennium the development of downstream PA and PF capacity in China gained momentum, initially displacing PF imports and subsequently providing a new supply source of PF exports.

The growth trend in global PF use was interrupted by the breakup of the former Soviet Union (FSU) at the end of the 1980s. The central planning system in the USSR had resulted in a high level of PF use (comparable on a $\mathrm{kg} / \mathrm{ha}$ basis with Europe) but a low level of use efficiency (i.e., yield per hectare). The sharp decline in $\mathrm{PF}$ use in the region, from nine million tons $\mathrm{P}_{2} \mathrm{O}_{5}$ in 1989 down to less than a million tons several years later, set the global PF demand back by a decade, even though growth continued in other regions. The sharp decline in PF use in the FSU was not matched by an equivalent drop in PF production, and, as a result, a new source of three million tons per year of PF exports emerged [60].

The growth in PF exports by the FSU, China, and traditional exporters mostly in North Africa and the Middle East was accompanied by attrition in export levels from the US. In particular, the phenomenal growth in PR and PF output in China from the 1990s onward led to the disappearance of an annual market for up to three million tons of mainly US PF products and the export from China of over three million tons of PF, again mostly displacing US tonnage in regional Asian markets. The US had already withdrawn from the PR-M market in the 1990s; the rising cost of PR production in Florida coupled with the decrease of product grades had led to this decision. In any case, the PR-M market was shrinking overall, with wholesale closure of PA capacity in Europe a particularly significant trend (prompted by economics and environmental pressures). PF production globally was moving from the location of PF consumption to the location of PR production. This form of integrated production is a comprehensible trend as (state-owned/state-controlled) PR-M producers want to increase their own value-adding.

\section{Policy Perspective: Connecting the Perspectives}

In the last 50 years, there have been two episodes when PR-M prices have increased sharply, by more than a factor of 5 , before falling once more to a long-term trend that shows a slow increase in nominal terms. These sharp spikes in prices, one in 1974/1975 and the other in 2007/2008 both prompted general concerns over the availability of PR. However, discussions about resource adequacy have been shown to have been a recurrent theme since World War II [61].

Both price-hike episodes highlighted the fact that $\mathrm{P}$ is an essential element for mankind. Chemical PF currently supports about half of current crop yields [3,14]. Currently, we mine over 300 million tons of PR-ore every year, predominantly to produce the food we eat. The fact that there is no substitution possible - no other element can perform the same task as phosphorus-leads to the supply of the element being essential [62]. 
The price hike in the 1970s prompted questions of resource adequacy [63] and research into available resources [64,65]. However, the more recent price in 2008 hike has led to wider discussions based not only around resource adequacy but also around the concepts of the right to feed oneself in dignity [66] and intra- and intergenerational fairness [67] incorporating multiple concepts:

- Is there a sufficient PR supply today?

- Will there be sufficient PR for future generations?

- Is the geographical concentration of resources a concern?

- Are geopolitical concerns valid?

- Should we be encouraging the recycling of $\mathrm{P}$ by economic incentives or legislation?

These are societally relevant questions that cannot be answered by science alone. Instead, knowledge integration across scientific and societal boundaries is a prerequisite from a transdisciplinary perspective to understand the underlying complex systems and to derive the guiding questions of relevance from both a societal and a scientific point of view. As briefly outlined in the Introduction, this requires appropriate methods of knowledge integration embedded in a transdisciplinary setting, which, e.g., builds on principles such as co-leadership between science and practice.

Multiple papers have been and continue to be written on these subjects. The importance of $P$ is now extending from academia to the popular press and to legislators. One result has been that, in 2014, the EU added PR to its list of critical minerals [38], and most recently, $\mathrm{P}_{4}$ has been added as well [10]. Ironically, much of the good work of spreading the discussion has come about through the scientifically incorrect notion that PR-ore reserves were becoming scarce and that a supply-driven peak in output would occur sometime in the 2030s [30,68,69]. The "peak phosphorus" theory was, in itself, flawed (e.g., [70-72]) as well as being based on data that, at best, needed revising and, indeed, were revised by the IFDC in 2011 [73]. However, "peak phosphorus" did capture headlines and continues to be referenced by some sources today.

The peak phosphorus debate has highlighted the need for good basic data. The availability of data in the public domain on PR supply, demand, trade, and resources is limited [74,75].

Four decades ago, the report by the Comptroller General to the Congress of the United States stated:

"For the purposes of public policymaking, then, it is necessary not only to have reliable data, but also an understanding of just what that data represents".

"We have found data used by the government to be deficient and inconsistent. In the past, figures on phosphate reserves have fluctuated inordinately, and they were presented with little explanation of the underlying assumptions necessary to use them for planning purposes". [63]

Private consulting companies, such as CRU International, invest significant time and money in the collection of good data to support their analyses, but these data are generally available only for a fee, and even then, their further use is usually restricted. There is a need for the development of a good publicly available data set that scientists can use without expert interpretation [75]. Without reliable data, political mistakes and scientific misconceptions are inevitable.

Unlike fossil fuels, we do not consume P; we merely dissipate it, eventually through rivers into seawater where it is essentially lost. This dissipation of $P$ sometimes results in socially undesirable outcomes in terms of algal blooms and eutrophication. The closing of loops in the phosphate chain is being addressed by many science and industry groups today in regard to developing a myriad of innovative processes to recover $\mathrm{P}$ as a nutrient from wastewater [76]; in terms of improving the efficiency of PF applications, for example through 4Rs nutrient stewardship (correct source, right rate, right time, and right place) [77]; in developing innovative processes for converting PR-ore into fertilizers, exemplified by the Improved Hard Process [78]; and in improving beneficiation and mining recoveries. Unlike in the 1970s, when the question was simply whether there was enough PR for the foreseeable future, today's research has a much wider range encompassing sustainability and 
intergenerational fairness, together with a recognition of the importance of $\mathrm{P}$ to humankind due to its nature as an essential and highly critical element.

\section{Conclusions}

Our aim is to provide and foster a holistic understanding of the underlying system dynamics to scientific peers, the public, respective companies, and policy makers. We integrated scientific knowledge and practical expert knowledge in a transdisciplinary sense to foster mutual learning among all stakeholders. Policy makers and high-level management personnel of phosphate companies are especially keys to manage this limited resource, which contributes to about half of today's global crop yield in the form of mineral fertilizers, in a more sustainable manner. Because of the transdisciplinary orientation of our work, we aim at an extended dissemination process, which goes beyond the pure provision of scientific, technical, and economic foundations of the phosphorus supply chain presented in this paper. Instead, we want to stimulate the mutual learning process between disciplines, but, most importantly, between science and practice by using our analysis within the scientific and practical arena as basis for an extended discourse and, ultimately, to help to improve the common understanding between scientists and practitioners with respect to key issues related to a sustainable phosphorus management. As vehicles for dissemination and an in-depth discourse, we will simultaneously use science and practice events and their networks for accomplishing this mission.

We cover the geological perspective including issues with contamination, the applied technology and necessary processes, as well as the major market mechanisms that determine levels of pricing and levels of product flows. We demonstrate that the economics of supply and demand are constantly changing for various reasons (e.g., geological, technological, and economical). Each market participant has to make economic calculations for each sale and purchase based on the economic goal of maximizing revenue.

However, in terms of intra- and intergenerational fairness, it is essential to add the environmental and social dimension to overriding goal setting.

Acknowledgments: We want to thank Roland W. Scholz and Friedrich-Wilhelm Wellmer for their valuable input and feedback and Elaine Ambrose for the thoughtful language editing of this paper.

Author Contributions: The paper emerged from the long-term cooperation of the authors within the Transdisciplinarity laboratory Sustainable Mineral Resources at Danube University Krems. Michael C. Mew contributed with his vast practical experience throughout the paper and especially in Sections 4 and 5. Gerald Steiner provided substantial and extensive feedback and contributed the sections on transdisciplinarity. Bernhard Geissler provided the basic structure and a draft for Sections 1-3. All authors collaborated equally on the conclusion.

Conflicts of Interest: The authors declare no conflict of interest.

\section{References}

1. Asimov, I. Asimov on Chemistry; Doubleday \& Company: Garden City, NY, USA, 1974; ISBN 978-0-385-04100-3.

2. Scholz, R.W.; Steiner, G. The real type and ideal type of transdisciplinary processes: Part I-Theoretical foundations. Sustain. Sci. 2015, 10, 527-544. [CrossRef]

3. Scholz, R.W.; Roy, A.H.; Hellums, D.T. Sustainable phosphorus management: A transdisciplinary challenge. In Sustainable Phosphorus Management; Scholz, R.W., Roy, A.H., Brand, F.S., Hellums, D.T., Ulrich, A.E., Eds.; Springer: Dordrecht, The Netherlands, 2014; pp. 1-128, ISBN 978-94-007-7249-6.

4. Nowotny, H.; Scott, P.B.; Gibbons, M.T. The New Production of Knowledge: The Dynamics of Science and Research in Contemporary Societies; Polity: Cambridge, UK, 2001.

5. Scholz, R.W.; Ulrich, A.E.; Eilittä, M.; Roy, A. Sustainable use of phosphorus: A finite resource. Sci. Total Environ. 2013, 461-462, 799-803. [CrossRef] [PubMed]

6. Scholz, R.W.; Roy, A.H.; Brand, F.S.; Hellums, D.T.; Ulrich, A.E. (Eds.) Sustainable Phosphorus Management: A Global Transdisciplinary Roadmap; Springer: New York, NY, USA, 2014; ISBN 978-94-007-7250-2. 
7. De Ridder, M.; de Jong, S.; Polchar, J.; Lingemann, S. Risks and Opportunities in the Global Phosphate Rock Market-Robust Strategies in Times of Uncertainty; The Hague Centre for Strategic Studies: Den Haag, The Netherlands, 2012.

8. Pohl, W.L. Mineralische und Energie-Rohstoffe: Eine Einführung zur Entstehung und Nachhaltigen Nutzung von Lagerstätten, 5th ed.; Schweizerbart: Stuttgart, Germany, 2005; ISBN 978-3-510-65212-9.

9. Steiner, G.; Geissler, B.; Watson, I.; Mew, M.C. Efficiency developments in phosphate rock mining over the last three decades. Resour. Conserv. Recycl. 2015, 105, 235-245. [CrossRef]

10. European Commission. Critical Raw Materials for the EU: 2017 List; European Commission: Brussels, Belgium, 2017.

11. Scholz, R.W.; Wellmer, F.-W. Approaching a dynamic view on the availability of mineral resources: What we may learn from the case of phosphorus? Glob. Environ. Chang. 2013, 23, 11-27. [CrossRef]

12. United States Geological Survey (USGS). Appendix C-Part A-A Resource/Reserve Classification for Minerals; USGS Mineral Resources Program: Reston, VA, USA, 2016.

13. Morse, D.E.; Glover, A.N. Minerals and Materials in the 20th Century-Review; USGS: Reston, VA, USA, 2000.

14. Erisman, J.W.; Sutton, M.A.; Galloway, J.; Klimont, Z.; Winiwarter, W. How a century of ammonia synthesis changed the world. Nat. Geosci. 2008, 1, 636-639. [CrossRef]

15. Stewart, W.M.; Dibb, D.W.; Johnston, A.E.; Smyth, T.J. The contribution of commercial fertilizer nutrients to food production. Agron. J. 2005, 97, 1-6. [CrossRef]

16. Scholz, R.W.; Wellmer, F.-W. Losses and use efficiencies along the phosphorus cycle-Part 2: Understanding the concept of efficiency. Resour. Conserv. Recycl. 2015, 105, 259-274. [CrossRef]

17. Geissler, B.; Scholz, R.W.; Steiner, G.; Mew, M.C. Clearing the smoke on phosphate data-Uncertainties, ambiguity, ignorance, and misunderstandings. Unpublished work. 2018.

18. Paarlberg, R.L. The United States of Excess: Gluttony and the Dark Side of American Exceptionalism; Oxford University Press: Oxford, UK; New York, NY, USA, 2015; ISBN 978-0-19-992262-8.

19. Jasinski, S.M. Phosphate Rock; Mineral Commodity Summaries; USGS: Reston, VA, USA, 2018; pp. $122-123$.

20. Jasinski, S.M. Phosphate Rock; Mineral Commodity Summaries; USGS: Reston, VA, USA, 2004; pp. $122-123$.

21. Gilbert, N. The Disappearing Nutrient. Nature 2009, 461, 716-718. [CrossRef] [PubMed]

22. United States Trade Representative Morocco Free Trade Agreement. Available online: https://ustr.gov/ trade-agreements / free-trade-agreements/morocco-fta (accessed on 19 October 2016).

23. European Commission Morocco-Trade-European Commission. Available online: http://ec.europa.eu/ trade/policy/countries-and-regions/countries/morocco/ (accessed on 19 October 2016).

24. Yaakoubi, A.E. Morocco Suspends Contacts with EU over Court Ruling on Farm Trade. Available online: http:/ / uk.reuters.com/article/uk-eu-morocco-westernsahara-idUKKCNOVY273 (accessed on 19 October 2016).

25. Yarime, M.; Carliell-Marquet, C.; Hellums, D.T.; Kalmykova, Y.; Lang, D.J.; Le, Q.B.; Malley, D.; Morf, L.S.; Matsubae, K.; Matsuo, M.; et al. Dissipation and recycling: What losses, what dissipation impacts, and what recycling options? In Sustainable Phosphorus Management; Scholz, R.W., Roy, A.H., Brand, F.S., Hellums, D.T., Ulrich, A.E., Eds.; Springer: Dordrecht, The Netherlands, 2014; pp. 247-274, ISBN 978-94-007-7249-6.

26. Scholz, R.W.; Wellmer, F.-W. Although there is no Physical Short-Term Scarcity of Phosphorus, its Resource Efficiency Should be Improved: Reasons to Improve Phosphorus Resource Efficiency. J. Ind. Ecol. 2018. [CrossRef]

27. Ohtake, H.; Tsuneda, S. (Eds.) Phosphorus Recovery and Recycling; Springer: Singapore, 2018; ISBN 978-981-10-8030-2.

28. Krauss, U.H.; Saam, H.G.; Schmidt, H.W. International Strategic Minerals Inventory Summary Report-Phosphate; U. S. Geological Survey: Alexandria, VA, USA, 1984.

29. Smil, V. Phosphorus in the Environment: Natural Flows and Human Interferences. Annu. Rev. Energy Environ. 2000, 25, 53-88. [CrossRef]

30. Cordell, D.; White, S. Peak phosphorus: Clarifying the key issues of a vigorous debate about long-term phosphorus security. Sustainability 2011, 3, 2027-2049. [CrossRef]

31. Van Enk, R.J.; Acera, L.K.; Schuiling, R.D.; Ehlert, P.; De Wilt, J.G.; Van Haren, R.J.F. The Phosphate Balance: Current Developments and Future Outlook; InnovationNetwerk: Utrecht, The Netherlands, 2011; ISBN 978-90-5059-414-1.

32. Rendu, J.-M. An Introduction to Cut-Off Grade Estimation, 2nd ed.; The Society for Mining, Metallurgy \& Exploration, Inc.: Englewood, CO, USA, 2014; ISBN 978-0-87335-393-9.

33. Geissler, B.; Mew, M.C.; Weber, O.; Steiner, G. Efficiency performance of the world's leading corporations in phosphate rock mining. Resour. Conserv. Recycl. 2015, 105, 246-258. [CrossRef] 
34. Haneklaus, N.; Sun, Y.; Bol, R.; Lottermoser, B.; Schnug, E. To Extract, or not to Extract Uranium from Phosphate Rock, that is the Question. Environ. Sci. Technol. 2017, 51, 753-754. [CrossRef] [PubMed]

35. Figueroa, E. Are more restrictive food cadmium standards justifiable health safety measures or opportunistic barriers to trade? An answer from economics and public health. Sci. Total Environ. 2008, 389, 1-9. [CrossRef]

36. Grant, C.A.; Sheppard, S.C. Fertilizer impacts on cadmium availability in agricultural soils and crops. Hum. Ecol. Risk Assess. Int. J. 2008, 14, 210-228. [CrossRef]

37. European Commission. Limits for Cadmium in Phosphate Fertilisers; Position Paper-Circular Economy Package; European Commission: Brussels, Belgium; Luxembourg, 2016.

38. European Commission. On the Review of the List of Critical Raw Materials for the EU and the Implementation of the Raw Materials Initiative; Communicaton from the Commission to the European Parliament, the Council, the European Economic and Social Committee and the Committee of the Regions; European Comission: Brussels, Belgium; Luxembourg, 2014; pp. 1-7.

39. Geissler, B.; Mew, M.C.; Matschullat, J.; Steiner, G. Contributing to circular P economy: The nexus between innovation and resource efficiency in phosphate rock mining. GAIA, submitted.

40. United States Department of the Interior; United States Geological Survey. Sedimentary Phosphate Resources Classification System of the U.S. Bureau of Mines and the U.S. Geological Survey; U.S. Geological Survey: Alexandria, VA, USA, 1982.

41. Wellmer, F.-W.; Dalheimer, M.; Wagner, M. Economic Evaluations in Exploration, 2nd ed.; Springer: Berlin, Germany; New York, NY, USA, 2008; ISBN 978-3-540-73557-1.

42. Van Kauwenbergh, S. World Phosphate Rock Reserves and Resources; IFDC: Muscle Shoals, AL, USA, 2010.

43. Kawatra, S.K.; Carlson, J.T. Beneficiation of Phosphate Ore; Society for Mining, Metallurgy \& Exploration Inc.: Englewood, CO, USA, 2013.

44. Kremmel, T. White Springs Operations 2010 Resource and Reserve Update Technical Report for White Springs Agricultural Chemicals; Marston \& Marston, Inc.: Ballwin, MO, USA, 2010.

45. JDCPhosphate, Inc. Phosphoric Acid Products Made from Phosphate Rock-JDC Phosphate. Available online: http:/ /jdcphosphate.com/phosphates-101/phosphoric-acid-products-made-from-phosphate-rock/ (accessed on 29 March 2018).

46. Scholz, R.W.; Wellmer, F.-W. Losses and use efficiencies along the phosphorus cycle-Part 1: Dilemmata and losses in the mines and other nodes of the supply chain. Resour. Conserv. Recycl. 2015, 105, 216-234. [CrossRef]

47. George, T.S.; Hinsinger, P.; Turner, B.L. Phosphorus in soils and plants-Facing phosphorus scarcity. Plant Soil 2016, 401, 1-6. [CrossRef]

48. Ashley, K.; Cordell, D.; Mavinic, D. A brief history of phosphorus: From the philosopher's stone to nutrient recovery and reuse. Chemosphere 2011, 84, 737-746. [CrossRef] [PubMed]

49. Pilarsky, G. Wirtschaft Am Rohstofftropf; Springer: Wiesbaden, Germany, 2014; ISBN 978-3-658-00362-3.

50. Mauss, R.; Posch, P.N. Marktpreisrisiken rohstoffintensiver Unternehmen-Identifikation und Management. In Strategische Rohstoffe-Risikovorsorge; Kausch, P., Bertau, M., Gutzmer, J., Matschullat, J., Eds.; Springer: Berlin/Heidelberg, Germany, 2014; pp. 39-57, ISBN 978-3-642-39704-2.

51. IndexMundi. Rock Phosphate-Monthly Price. Available online: https://www.indexmundi.com/ commodities / ?commodity=rock-phosphate (accessed on 5 January 2018).

52. World Bank. Commodity Markets-Pink Sheets. Available online: http://www.worldbank.org/en/ research/commodity-markets (accessed on 5 January 2018).

53. Tilton, J.E.; Guzmán, J.I. Mineral Economics and Policy; RFF Press: Washington, DC, USA, 2016; ISBN 978-1-61726-088-9.

54. Wellmer, F.-W.; Hagelüken, C. The feedback control cycle of mineral supply, increase of raw material efficiency, and sustainable development. Minerals 2015, 5, 815-836. [CrossRef]

55. Wellmer, F.-W.; Dalheimer, M. The feedback control cycle as regulator of past and future mineral supply. Miner. Depos. 2012, 47, 713-729. [CrossRef]

56. Tilton, J.E. Assessing the market power of mineral commodity producers. Miner. Econ. 2017. [CrossRef]

57. ICC. Incoterms Rules 2010; International Chamber of Commerce (ICC): Paris, France, 2010.

58. Persky, J. Retrospectives: The ethology of homo economicus. J. Econ. Perspect. 1995, 9, 221-231. [CrossRef] 
59. Weber, O.; Delince, J.; Duan, Y.; Maene, L.; McDaniels, T.; Mew, M.; Schneidewind, U.; Steiner, G. Trade and finance as cross-cutting issues in the global phosphate and fertilizer market. In Sustainable Phosphorus Management; Scholz, R.W., Roy, A.H., Brand, F.S., Hellums, D.T., Ulrich, A.E., Eds.; Springer: Dordrecht, The Netherlands, 2014; pp. 275-299, ISBN 978-94-007-7249-6.

60. Prud'homme, M. World Phosphate Rock Flows, Losses and Uses. In Proceedings of the Phosphates 2010 International Conference on International Fertilizer Industry Association, Brussels, Belgium, 22-24 March 2010.

61. Ulrich, A.E.; Frossard, E. On the history of a reoccurring concept: Phosphorus scarcity. Sci. Total Environ. 2014, 490, 694-707. [CrossRef] [PubMed]

62. Wellmer, F.-W.; Scholz, R.W. Peak minerals: What can we learn from the history of mineral economics and the case of gold and phosphorus? Minerals 2017, 30, 73-93. [CrossRef]

63. Committee on National Materials Policy Planning Process. The Comptroller General Phosphates: A Case Study of a Valuable, Depleting Mineral in America; National Academy Press: Washington, WA, USA, 1979.

64. Notholt, A.J.G.; Sheldon, R.P.; Davidson, D.F. International Geological Correlation Programme; Project 156 Phosphorites. Phosphate Deposits of the World; Cambridge University Press: Cambridge, UK, 2005; ISBN 978-0-521-67333-4.

65. Cook, P.J.; Shergold, J.H. Programme international de corrélation géologique; Projet (156); Proterozoic and Cambrian Phosphorites; Cambridge University Press: Cambridge/London, UK; New York, NY, USA, 1986; ISBN 978-0-521-25034-4.

66. Ziegler, J. Report of the Special Rapporteur on the Right to Food; UN Human Rights Council: Geneva, Switzerland, 2008.

67. Brundtland, G.H. Report of the World Commission on Environment and Development: Our Common Future; World Commission on Environment and Development: Oslo, Norway, 1987.

68. Dery, P.; Anderson, B. Peak Phosphorus; Energy Bulletin: Santa Rosa, CA, USA, 2007; Available online: http:/ / www.energybulletin.net/node/33164 (accessed on 04 April 2018).

69. GPRI. Global Phosphorus Research Initiative-Public Consultation on the Raw Materials Initiative. Available online: http:/ / phosphorusfutures.net/wp-content/uploads/2015/02/GPRI_submission_EU_ CriticalRawMaterials.pdf (accessed on 20 March 2018).

70. Scholz, R.W.; Wellmer, F.-W. Comment on: “Recent revisions of phosphate rock reserves and resources: A critique" by Edixhoven et al. (2014)—Clarifying comments and thoughts on key conceptions, conclusions and interpretation to allow for sustainable action. Earth Syst. Dyn. 2016, 7, 1-15. [CrossRef]

71. Scholz, R.W.; Wellmer, F.-W. Interactive comment on "Recent revisions of phosphate rock reserves and resources: Reassuring or misleading? An in-depth literature review of global estimates of phosphate rock reserves and resources" by Edixhoven et al. Earth Syst. Dyn. Discuss. 2013, 4, C574-C598.

72. Geissler, B.; Steiner, G. Interactive comment on “Comment on: 'Recent revisions of phosphate rock reserves and resources: A critique' by Edixhoven et al. (2014)_Phosphate reserves and resources: What conceptions and data do stakeholders need for sustainable action?" by R.W. Scholz et al. (2015). Earth Syst. Dyn. Discuss. 2015, 6, C56-C68.

73. Van Kauwenberg, S. Phosphate Forecast: How Far Can We Go (How Deep Can We Dig?); Centre for the Development of Fertilizer Technology, Universidade Federal de Uberlandia: Santa Mônica, Brazil, 2011.

74. Edixhoven, J.D.; Gupta, J.; Savenije, H.H.G. Recent revisions of phosphate rock reserves and resources: A critique. Earth Syst. Dyn. 2014, 5, 491-507. [CrossRef]

75. Wellmer, F.-W.; Scholz, R.W. The right to know the geopotential of minerals for ensuring food supply security: The case of phosphorus. J. Ind. Ecol. 2015, 19, 3-6. [CrossRef]

76. Schipper, W. Phosphorus Recycling Technologies and Legislation: Update and Outlook; Global Phosphorus Forum: Paris, France, 2016.

77. Johnston, A.M.; Bruulsema, T.W. 4R nutrient stewardship for improved nutrient use efficiency. Procedia Eng. 2014, 83, 365-370. [CrossRef]

78. Blake, D. The Improved Hard Process: Current Status and Next Steps. 2017. Available online: https:/ /www. avenira.com/wp-content/uploads/2017/03/JDC-Phosphate-David-Blake.pdf (accessed on 20 March 2018).

(C) 2018 by the authors. Licensee MDPI, Basel, Switzerland. This article is an open access article distributed under the terms and conditions of the Creative Commons Attribution (CC BY) license (http:/ / creativecommons.org/licenses/by/4.0/). 